\title{
Mogens Hylledig:
}

\section{Nyere ledelsessynspunkter i USA's industri}

Denne artikel er et foredrag holdt den 11/10 1968 på Industrifagenes (en arbejdsgiverorganisation) generalforsamling af den daværende industrikonsulent Mogens Hylledig. Den viser klart, hvorledes virksomhedslederne med eller mod deres vilje er tvunget til at modernisere deres antagelser og ledelsesmetoder for at kunne klare sig i konkurrencen om markedet og for at kunne bevare den kapitalistiske produktionsmåde. Foredraget er sammen med bogen »USA $i 1968$ - Danmark $i$ 70'erne? « udtryk for introduktionsfasen af den moderne virksomhedsledelse i Danmark; senere er man gået over til praktiske eksperimenter på flere store fabrikker. 


\section{[Rejsen til USA i 1968]}

Det billede af nyere ledelsessynspunkter i USA's industri, som jeg i den kommende halve timestid skal forsøge at gengive, er et billede, som har dannet sig ved bundfældelse af en lang række indtryk fra en studierejse på 4-5 uger i april-maj måned i år.

Rejsen blev arrangeret af Sekretariatet for Danmarks Erhvervsfond med det formål at konstatere udviklingen i ledelsesmetoder og arbejdsforhold inden for den amerikanske industri, siden man i 1955 gennemførte en tilsvarende rejse.

I rejsen her i foråret deltog 15 konsulenter fra de teknologiske institutter, fra Industrirådet, Dansk Arbejdsgiverforening, LO og andre af arbejdsmarkedets organisationer, herunder altså også fra Industrifagene.

Med hensyn til selve rejsen skal jeg kort nævne, at holdet på de første $2 \frac{1}{2} 2$ uge besøgte organisationer, institutioner, universiteter og konsulentfirmaer i New York, Washington og Boston, dernæst tilbragte en uge med virksomhedsbesøg i de nordøstlige stater og endelig den sidste uge tog den store tur med virksomhedsbesøg i Texas og universitetsbesøg i Los Angeles.

Rejsen var planlagt af industriattaché Anker Hansen fra den danske ambassade i Washington og med bistand af en professor fra New Yorks universitet. Man havde især lagt vægt på at bringe os i kontakt med de personer og virksomheder, som repræsenterer - og praktiserer - de nyeste synspunkter indenfor amerikansk virksomhedsledelse.

Det er disse synspunkter, jeg skal forsøge at redegøre for, men jeg vil understrege, at de på ingen måde er generelt accepteret eller anvendt i USA - i hvert fald ikke endnu. Men de steder, hvor de bliver anvendt, har resultaterne været så iøjnefaldende gode, at jeg godt tør spå, at de med tiden vil få en større udbredelse, ikke blot i USA, men også i de vesteuropæiske industrisamfund.

\section{[Automation og humanation]}

Baggrunden for disse synspunkter er erkendelsen af, at der er to midler, man kan tage i anvendelse for at effektivisere en industrivirksomhed. Det ene middel er forøgelse af maskinernes effektivitet - amerikanerne taler om automation - det andet er forøgelse af menneske- nes produktivitet - som amerikanerne kalder for humanation.

Med hensyn til automationen - eller skal vi nøjes med at sige produktionsudstyret - bragte rejsen ingen større overraskelser. Vi vidste jo godt på forhånd, at EDB teknik og numerisk styrede maskiner har en langt større udbredelse i USA end her i landet, men bortset fra enkelte undtagelser virkede produktionsudstyret i de virksomheder, vi besøgte, ikke imponerende.

Jeg vil dog skynde mig at tilføje, at man utvivlsomt let kunne tilrettelægge en rejse, der giver det stik modsatte indtryk på dette område.

Men vores rejse var jo som sagt planlagt for at give os et indtryk af den udvikling, som foregår på det andet område - på humanationsiden.

Det spørgsmål, som mange af de virksomhedsledere, vi mødte, kredsede om, var spørgsmålet: Hvordan skal vi bære os ad med at gøre vore folk mere effektive? $\mathrm{Og}$ den måde, man besvarede dette spørgsmål på, var ganske overraskende.

\section{[Den traditionelle ledelsesform og dens pramisser]}

For at kunne forklare de nye synspunkter med hensyn til, hvordan man får folk til at arbejde mere effektivt, er det nødvendigt at tage udgangspunkt i den opfattelse af menneskers indstilling, som danner grundlaget for vore hidtidige ledelsesformer - uanset hvor forskellig de i øvrigt har været.

Den opfattelse er, at folk ikke bryder sig om at arbejde, at det er nødvendigt at fortælle dem nøjagtigt, hvad de skal gøre og hvordan de skal gøre det, og at de så vidt muligt søger at undgå enhver form for selvstændigt ansvar.

Lad os prøve at se på nogle af de ledelsesformer, som er baseret på denne antagelse:

Den ældste - og enkleste - måde at få folk til at bestille noget på, er fysisk magtanvendelse. Når man skulle have galejslaverne - i gamle dage til at trække noget kraftigere i årerne, så var det et udmærket middel at kaste den svageste af dem overbord.

Metoden har naturligvis nogle ulemper det nytter jo ikke noget at smide alle slaverne $\mathrm{i}$ vandet eller sætte alle bønderne på træhesten men den blev alligevel betragtet som en effektiv, produktionsfremmende ledelsesform i adskillige tusinde år. 
Metoden anvendes - i hvert fald efter amerikanernes opfattelse - endnu i dag i visse dele af verden, men i de vestlige industrilande blev anvendelsen af afstraffelse som drivmiddel forladt omkring århundredeskiftet - undtagen i skolerne og indenfor militæret - og der findes formentlig kun meget få virksomhedsledere inden for vores kulturkreds, som kunne tænke sig en tilbagevenden til denne form for ledelse.

Efterhånden som mulighederne for at benytte sig af folks frygt for at lide fysisk overlast, hvis de ikke bestilte noget, blev reduceret, gik man over til at basere sin ledelse på en anden form for frygt - nemlig folks frygt for at miste deres arbejde og dermed deres eksistensgrundlag.

Dette ledelsesmiddel taber ganske vist i værdi i perioder med mangel på arbejdskraft - som også kendes i USA, specielt hvad angår kvalificeret arbejdskraft - men den betragtes stadig af nogle ledere, både i USA og her i landet, som et velegnet middel til at opnå en effektiv arbejdsindsats.

Sideløbende med disse to mere primitive midler har man igennem århundreder benyttet sig af autoritet som ledelsesmiddel - altså af den naturlige respekt folk nærer for deres overmænd. Og ved at udstyre lederne med ydre kendetegn på autoritet - som vi jo stadig ser anvendt f.eks. indenfor militæret - har man ment det muligt at overføre denne respekt også til personer, der måske ikke var i besiddelse af en naturlig autoritet.

Lederne har således forsøgt at udnytte den fordel, de har haft, bl.a. i kraft af en bedre uddannelse, men efterhånden som hele befolkningens uddannelsesniveau er blevet hævet, er det samtidig blevet vanskeligere at opretholde autoriteten blot ved hjælp af ydre kendetegn som f.eks. de mange striber på ærmet eller den brune eller hvide kittel.

Da også denne ledelsesform derfor så småt begyndte at tabe i værdi, så man sig nødsaget til at søge andre midler, og man fandt da på at tage det gammelkendte system med anvendelse af belønninger op i moderniseret form ved at lade den enkelte arbejders betaling være direkte afhængig af hans produktion.

Dette system virkede fortræffeligt i en årrække, men efterhånden som mekanisering og automatisering er skredet frem, er det i stadig større udstrækning blevet maskinerne og ikke arbejderne, som bestemmer produktionens størrelse. Og selv på de steder, hvor arbejderen stadig kan påvirke tempoet, skal der - med det lønniveau man har i dag - lokkes med en bety- delig merfortjeneste for at opnå en højere indsats fra arbejdernes side.

Hertil kommer forskellige andre ulemper. F.eks. kan en ensidig belønning for kvantitet medføre forringelse af kvaliteten, og dette blev omtalt som en meget udbredt foreteelse i USA. Man fortalte os f.eks. som et kuriosum, at mange kvalitetskontrolingeniører fra de amerikanske automobilfabrikker køber europæiske biler til sig selv af denne grund.

Også administrationen af akkordsystemerne og vedligeholdelsen af akkordgrundlaget er et voksende problem, efterhånden som produkternes levetid bliver stadig kortere og fremstillingsteknikken forbedres stadig hyppigere. $\mathrm{Og}$ planlægning af produktionen vanskeliggøres, fordi arbejderne protesterer mod at blive flyttet fra et arbejde til et andet.

Som ledelsesmiddel vil akkordsystemet derfor ikke være særlig velegnet på længere sigt, og der er i USA - efter amerikanske lederes udtalelser - en tendens til at forlade dette aflønningssystem, selv om nogle mente, at det ville vise sig at være et forbigående fænomen.

\section{[Andring nødvendig for at bevare kapitalismen]}

Under alle omstændigheder gav adskillige af de ledere, vi talte med, udtryk for den opfattelse, at de traditionelle ledelsesformer ikke længere slår til. Man kan i dag hverken true, narre eller lokke folk til at arbejde mere effektivt.

Dette er i sig selv galt nok, set fra et snævert ledelsesmæssigt synspunkt, men nogle af de ledere, vi mødte, gav udtryk for en fornemmelse af, at en ændring af de hidtidige ledelsesmetoder er nødvendig, dersom industrien skal bevare sin nuværende stilling i samfundet.

Disse ledere tager foreteelser som studenteroprør og flower-power-bevægelse som tegn på, at der i befolkningen findes et behov - som [det] måske er vanskeligt at definere - men som man alligevel må forsøge at imødekomme, dersom man vil undgå, at det kapitalistiske samfundssystem på længere sigt bringes i fare.

Man søger derfor at finde frem til nye og mere tidssvarende ledelsesmetoder, og som det første skridt ad denne vej har man taget den hidtidige opfattelse af menneskelig adfærd op til revision - ikke mindst fordi de undersøgelser, som er blevet foretaget af sociologer og psykologer igennem den sidste halve snes år, har sat nogle store spørgsmålstegn ved 
rigtigheden af den traditionelle opfattelse på nogle af de vigtigste punkter.

\section{[Nyere arbejdspsykologiske undersøgelser]}

Medens man som den fremherskende opfattelse hidtil har ment, at folk i almindelighed ikke bryder sig om at arbejde, har undersøgelserne vist, at det at bestille noget er en normal form for menneskelig udfoldelse, og at normale mennesker under de rette betingelser derfor gerne vil arbejde.

I følge sociologerne er en af disse betingelser, at folk får en vis mulighed for at træffe beslutninger med hensyn til, hvad de gør og hvordan de gør det. Dette er altså i modstrid med den traditionelle opfattelse: at det er nødvendigt at fortælle folk nøjagtigt hvad de skal gøre, og hvordan de skal gøre det.

Også den traditionelle antagelse om, at folk så vidt muligt vil undgå enhver form for selvstændigt ansvar er blevet imødegået. Undersøgelser har vist, at folk, når de rette betingelser er til stede, gerne vil påtage sig ansvaret for at nå de fastsatte mål - f.eks. kvalitetsmål eller produktionsmål. De rette betingelser er her, at folk selv har haft indflydelse på fastsættelsen af disse mål.

$\mathrm{Og}$ endelig siger undersøgelserne, at folk ikke arbejder alene for pengenes skyld. Betalingen er naturligvis en vigtig faktor, og folk forventer at blive aflønnet i overensstemmelse med deres ydelser, men når blot de føler, at den løn de modtager er rimelig, er der en række andre faktorer, som øver indflydelse på deres præstation.

Der er altså tale om en temmelig dybtgående uoverensstemmelse mellem de undersøgelsesresultater, sociologer og psykologer har kunnet fremvise, og de traditionelle antagelser, vi hidtil har baseret vores ledelsesformer på. Hvis undersøgelsesresultaterne taler sandt, er det altså ikke så underligt, at vore hidtidige ledelsesmetoder har vist sig utilstrækkelige i et moderne samfund.

$\mathrm{Nu}$ kan jeg forestille mig, at en del af Dem sidder og tænker: Det lyder meget kønt, men hvordan skulle vore virksomheder kunne arbejde effektivt, hvis vi lader vore arbejdere selv bestemme, hvad de vil lave, hvordan de vil lave det, og hvor meget de har lyst til at lave. Vi kan ikke bygge vore virksomheders fremtid på, at alle vore arbejdere er glade og tilfredse, virksomhedernes - og dermed også arbejdernes eksistens beror alene på en effektiv produktion.
Jeg kan betro Dem, at studieholdets deltagere havde nøjagtig den samme indstilling, efter at vi under den første halvdel af rejsen havde hørt om disse teorier på universiteterne og hos forskellige konsulentfirmaer.

\section{[Eksperiment: Kodak]}

Nogle af deltagerne gik endda så vidt som til at erklære, at rejseprogrammet måtte revideres, så vi blev fri for at høre mere »humanation-gas « og i stedet fik set nogle effektive planlægningssystemer, EDB-løsninger og andre konkrete ledelsesværktøjer.

$\mathrm{Nu}$ var det jo af praktiske grunde umuligt at ændre planerne for rejsens sidste halvdel - og det var godt det samme. For netop ved fabriksbesøgene på den sidste del af rejsen, fik vi lejlighed til at stifte bekendtskab med nogle af de virksomheder, hvor man har taget ledelsesformer i anvendelse, som er i overensstemmelse med de nye teorier.

Og de resultater man herved havde opnået i retning af effektivitetsforbedringer var så overbevisende, at selv de største skeptikere på holdet måtte erkende, at det ville være forkert blot at afvise det som naiv snak uden hold i virkeligheden.

Det var kendetegnende for de virksomheder vi besøgte, at der havde været en højtstående leder, som var gået positivt ind for at forsøge at omsætte de nye tanker til praktisk handling.

På Kodak's store fabrik i Rochester i den nordlige del af staten New York, hvor 26.000 mennesker er beskæftiget med fremstilling af fotografisk film, papir og kemikalier, har Georg Gustat været initiativtageren. Han er leder af rationaliseringsafdelingen, som har ca. 500 medarbejdere. I hans afdeling begyndte man for en halv snes år siden at føle, at de forskellige former for akkord- og bonussystemer, som har været anvendt hos Kodak siden 1913, var ved at have udspillet deres rolle.

Dels fordi der måtte gives procentvis stadig større tillæg til normallønnen for at opnå højere arbejdsydelser, dels fordi produktionen var blevet automatiseret, således at udnyttelsen af maskiner og materialer var blevet af væsentlig betydning.

Man begyndte derfor i rationaliseringsafdelingen at interessere sig for psykologernes undersøgelser, og da man ikke rigtig kunne forstå deres bøger, ansatte man selv en psykolog i 1960 .

Det hjalp ikke på kommunikationen lige med det samme, men efter at psykologen havde 
arbejdet $\mathrm{i}$ afdelingen et års tid og var blevet uddannet som arbejdsstudiemand, begyndte man at tale samme sprog. Derefter gik man i gang med at omsætte teorierne til praktisk handling.

Det første man gjorde var at intensivere og systematisere den interne uddannelse af folkene, så de fik en bredere forståelse for maskiner, processer, materialer, metoder, o.s.v. Samtidig inddelte man de forskellige typer af arbejde i 5-6 klasser efter sværhedsgrad og etablerede et lønsystem, baseret på denne opdeling, altså arbejdsvurdering.

Oplæringen blev derefter planlagt individuelt for hver enkelt medarbejder med det formål at gøre ham kvalificeret til et højere lønnet arbejde. Såvel planlægningen som gennemførelsen af denne oplæring påhviler arbejdernes nærmeste overordnede, altså formanden. På tilsvarende måde påhviler det enhver leder i organisationen at sørge for at udvikle sine nærmeste underordnede. Kodak oplyser, at ca. $10 \%$ af al arbejdstid benyttes til uddannelse.

Efterhånden som man herved fik skabt det fornødne grundlag, blev der etableret grupper, hver bestående af en formand og hans medarbejdere. Disse grupper mødes nogle gange om ugen i arbejdstiden og drøfter arbejdets forløb, herunder muligheden for at forbedre kvaliteten og for at forøge produktionen.

Det er arbejderne, der tegner sig for de $90 \%$ af indlæggene på disse møder, og det er også arbejderne, som sammen med deres formand fastsætter de produktionsnormer, som siden indgår i virksomhedens produktionsbudgetter.

Denne nye ledelsesmetode er foreløbig indført i afdelinger, som omfatter 4-5.000 arbejdere. Resultaterne har været formidable. I 1967 blev forbruget af arbejdsløn pr. enhed reduceret med 25\% uden anskaffelse af nyt udstyr - og det er jo særlig forbløffende i en virksomhed, som i over 50 år har haft metodestudieingeniører og produktivitetsfremmende lønsystemer.

Desuden var spildprocenten blevet væsentligt reduceret, og kvaliteten var blevet forbedret, så der havde været langt færre reklamationer fra kunderne. Arbejdernes fravær gik ned fra 12 dage pr. år til 5 dage årligt som gennemsnit.

Georg Gustat sagde: »Der er stort potentiel i vore medarbejdere, og det forsøger vi at frigøre ved at skabe et miljø, hvor alle arbejder sammen på opfyldelsen af fælles mål. Vi er kun lige begyndt at omsætte psykologernes idéer til praktisk handling, og vi har ingen patentløsninger, men nok en vis strategi«.

\section{[Eksperiment: Texas Instruments]}

En tilsvarende strategi så vi også anvendt små 3.000 km fra Kodak's fabrik, nemlig på nogle virksomheder i Texas. Den største af dem var Texas Instruments, som beskæftiger ca. 40.000 mennesker på fabrikker forskellige steder i USA samt England, Frankrig og Australien.

Det er et af de førende firmaer indenfor elektronik, en branche hvor den teknologiske udvikling jo er voldsom, og hvor konkurrencen er hård. Ofte afhænger en ordre af, om man med kort varsel kan fremstille en serie komponenter efter kundens specifikationer.

For at kunne leve op til disse krav er det bl.a. nødvendigt, at alle ansatte til stadighed søger at effektivisere deres job, og for at opnå dette havde man igennem mange år undervist arbejderne i arbejdsforenklingens teknik.

Denne undervisning var oprindeligt tilrettelagt på traditionel måde, d.v.s. som klasseundervisning, der blev givet af stabsfolk fra uddannelsesafdelingen, og som et led i denne undervisning havde hver arbejder fået til opgave at finde et job i sin afdeling, som kunne forbedres, og at gennemføre forbedringerne ved at anvende den teknik, hun havde lært. - Jeg siger med vilje hun, fordi langt den overvejende del af arbejderne er kvinder.

Ideen var, at man ad denne vej skulle få startet et omfattende effektiviseringsprogram, men den viste sig at være uigennemførlig, fordi man var gået uden om formændene. De så det stadig som deres primære opgave at få produktionen gennemført på en effektiv måde, og de var derfor ikke interesseret $i$, at deres arbejdere brugte alt for meget af den kostbare arbejdstid på forbedringsopgaver.

Derfor sørgede de for altid at have nogle forbedringsprojekter liggende klar i skrivebordsskuffen, som de arbejdere, eller arbejdersker, der havde været på kursus hurtigt kunne lave færdige og aflevere til deres lærer. Hele effektiviseringsprogrammet degraderedes til en slags spil, som man kan kalde »et projekt for projektets skyld«, og det afgik derfor efterhånden ved en naturlig død.

Først så sent som i 1965 kom der for alvor liv i effektiviseringsprogrammet. Livredderen hedder Bill Dees, og han er produktionschef for et fabriksafsnit med 7 afdelingsledere, 80 formænd og godt 3.000 arbejdere.

Under sin deltagelse i et større externt kursus i arbejdsforenkling blev han klar over, at svag- 
heden ved det hidtidige system havde været formændenes manglende engagement i sagen og da han ønskede, at afdelingslederne skulle komme til samme konklusion, fik han arrangeret et tilsvarende kursus for dem internt i virksomheden.

Efter at de havde gennemgået dette kursus, kom afdelingslederne til ham og sagde, at det var nødvendigt at få formændene gjort positive. Det syntes Bill Dees også, og han pålagde derfor afdelingslederne med bistand fra uddannelsesafdelingen, at gennemføre kurser for formændene.

Herved fik samtlige formænd i løbet af efteråret 1965 en 18-timers uddannelse i arbejdsforenkling. I forbindelse hermed blev formændene klar over, at hvis effektiviseringsprogrammet skulle blive virkelig effektivt, måtte de selv uddanne arbejderne.

$\mathrm{Nu}$ var det jo umuligt at uddanne alle 3.000 arbejdere på een gang, og derfor fik formændene den idé at opdele arbejderne i grupper bestående af kvinder, som udførte det samme arbejde eller arbejdede ved samme produktionslinie.

Der blev ialt dannet 75 grupper, med imellem 5 til 50 arbejdere. Hver gruppe valgte sin egen gruppeleder, og i foråret 1966 underviste formændene disse gruppeledere i arbejdsforenklingens teknik.

Derefter holdt hver gruppeleder møde med sin gruppe ca. een gang om ugen. Hun opmuntrede sine kammerater til at komme med idéer, hjalp dem med at indsamle de nødvendige oplysninger, og styrede diskussionen i gruppen omkring forslaget. I forbindelse med denne diskussion fastlagde gruppen selv det produktionsmål, der ville kunne opnås, dersom forslaget gennemførtes.

Hvis gruppen godkendte et forslag, hjalp gruppelederen forslagsstilleren med at forelægge det for formanden, og hvis han godkendte det, blev det derpå omgående ført ud i livet.

Jobbet som gruppeleder går på skift mellem gruppens medlemmer, idet gruppen selv udpeger en ny gruppeleder 2-3 gange om året. På denne måde er det blevet en permanent opgave for formændene at uddanne deres arbejdere, og med udgangen af dette år regner man med, at ialt omkring 10.000 arbejdere vil have fået denne undervisning siden starten i 1966.

Også hos Texas Instruments har resultaterne været forbløffende. Umiddelbart havde man ikke store forventninger med hensyn til, at fabriksarbejdersker, som f.eks. sidder og samler transistorer, skulle kunne komme med virkelig betydningsfulde idéer til forbedring af arbejdsmetoderne.

Men efterhånden som man modtog det ene forslag efter det andet, begyndte både formænd og afdelingsledere at se på deres folk med nye øjne. Allerede det første år, altså i 1966, medførte arbejdernes forslag besparelser i Bill Dees' afdelinger på omkring 1 mill. dollars pr. år.

Over en 18-måneders periode overskred arbejderne deres egne produktionsmål med 20\%, og disse produktionsmål var højere end de standards virksomheden tidligere havde regnet med. I andre afdelinger har man opnået tilsvarende gode resultater. Man nævnte flere eksempler på, at produktionstiden var blevet på det nærmeste halveret.

Men hertil kom, at arbejdernes indstilling ændrede sig. Hvor de tidligere bare skulle udføre noget ensformigt arbejde, ser de det nu som deres opgave at planlægge, gennemføre og kontrollere arbejdsmetoderne.

De føler sig nu ikke længere blot som det vi herhjemme kalder for lønslaver, amerikanerne kalder det for »hired hands«, men synes, at de nu bliver betragtet som rigtige mennesker med både intelligens og initiativ. Antallet af forsømmelser er faldet til under 1\%. Denne udvikling kom ikke helt uventet for Texas Instruments, tværtimod bekræftede den resultaterne af en undersøgelse, som personaleafdelingens psykologer gennemførte i årene 1961-1963 med henblik på at fastslå, hvilke midler man kan anvende for at motivere folk, altså for at engagere dem personligt.

Jeg skal ikke trætte Dem med en redegørelse for selve undersøgelsens forløb, men blot ganske kort referere dens resultater, fordi vi herved får et fingerpeg om, i hvilken retning vi skal gå under vores jagt efter nye og mere effektive ledelsesformer.

\section{[Motivationsfaktorer og vedligeholdelsesfaktorer]}

Undersøgelsen viste, at man kan opdele de faktorer vi betjener os af i vores personaleledelse, i to kategorier af vidt forskellig art. Den ene kategori indeholder de foranstaltninger af mere officiel karakter, som gennemføres af virksomhedens øverste ledelse og gælder for større grupper af medarbejdere, medens den anden indeholder de foranstaltninger, som retter sig direkte mod den enkelte medarbejder.

Til den første kategori hører de økonomiske foranstaltninger, først og fremmest naturligvis 
lønnen, desuden tryghedsforanstaltninger som f.eks. opsigelsesvarsler og anciennitetsregler, orientering f.eks. gennem personaleblade og opslagstavler, statussymboler f.eks. i form at titler, reserverede parkeringspladser eller gulvtæpper, velfærdsforanstaltninger. som f.eks. firmaskovture, sommerhuse eller kunstforeninger, og endelig de fysiske forhold som gode arbejdslokaler og lignende.

Fælles for alle disse foranstaltninger er, at de ikke har nogen blivende værdi som motivationsfaktor. Man får ikke folk til at arbejde mere effektivt ved at give dem længere opsigelsesvarsel, finere titler eller reserveret parkeringspladser. Heller ikke ved at give dem mere i løn.

Alligevel er de vigtige, for hvis folks forventninger på disse områder ikke imødekommes, opstår der utilfredshed. Og det er gennemførelsen af disse foranstaltninger, som koster industrien stadig flere penge.

Den anden kategori af foranstaltninger koster derimod relativt færre penge - og det er måske derfor, det har været så svært at få øje på dem. Det er som næunt foranstaltninger, der er rettet mod det enkelte individ - og som hver enkelt leder derfor personligt må iværksætte over for sine underordnede. Amerikanerne har grupperet disse positive motivationsfaktorer omkring fire ord.

Det første er ordet udvikling. Man må give sine folk lejlighed til at udvikle sig, både personligt og professionelt. Mulighederne herfor er naturligvis størst for de højere lag i organisationen, men behovet for udvikling findes også hos de menige arbejdere, og det kan imødekommes, således som vi har set det hos bl.a. Kodak og Texas Instruments.

Også mange andre steder i USA er man klar over betydningen af at imødekomme dette behov, og det var almindeligt, at lederne et par gange om året drøftede med hver enkelt af deres underordnede, hvad han eller hun kunne gøre for at udvikle og dygtiggøre sig yderligere.

Udvikling af alle ansatte er en vigtig forudsætning for den anden motivationsfaktor, som er handlemulighed, d.v.s. folks mulighed for at planlægge egne handlinger, at sætte sig mål og derpå se resultaterne.

Man illustrerede betydningen heraf ved at nævne keglespilleren, som sætter sit mål - at vælte keglerne - gennemfører handlingen og straks ser resultatet. Hvis man hænger et tæppe ned midt på keglebanen kan han hverken se målet eller resultaterne, og så kommer keglespillet til at ligne et normalt kedeligt, ensformigt industriarbejde.

Hvis vi omvendt $\mathrm{i}$ industrien giver vore folk mulighed for at sætte sig produktionsmål og selv kontrollere om de nås - ja så skifter arbejdets karakter, så får det en mening, så bliver det en sport at opnå stadig bedre resultater, sådan som vi har set det i de eksempler, jeg har omtalt.

Nært sammenknyttet med behovene for udvikling og handlemulighed er ønsket om ansvar hos medarbejderne. Det er ikke nok at lade folk føle sig ansvarlige, man må lade dem være ansvarlige - hvilket bl.a. indebærer, at man må tillade dem at begå fejl og lære deraf som et led i deres personlige og professionelle udvikling.

En person, som får overladt ansvaret for en opgaves gennemførelse betragter dette som et tegn på ledelsens tiltro til hans evner, og han vil gøre en ekstra indsats for at bevise, at han har disse evner - både overfor ledelsen og især overfor sig selv.

Naturligvis skal man ikke give folk ansvaret for opgaver, de ikke har forudsætninger for at magte, og derfor er systematisk, planlagt uddannelse nødvendig, men resultaterne fra Texas Instruments' arbejdsforenklingsgrupper viser, at folks evner er større, end man normalt antager.

Og endelig peger undersøgelsen på en fjerde motivationsfaktor - og den, som samtidig er vanskeligst at administrere, nemlig anerkendelse - vel at mærke fortjent og ærligt ment anerkendelse. Her kommer motivationsfaktorernes personlige karakter tydeligt frem. Det er den enkelte leders opgave at påskønne medarbejdernes indsats firmaet som sådant påskønner ikke nogen. Der stilles med andre ord særlige krav til den enkelte leders menneskelige egenskaber.

Amerikanerne har altså fundet, at der er fire faktorer, som må tages i anvendelse for at motivere folk: Udvikling - handlemulighed - ansvar og anerkendelse. De øvrige faktorer: løn, velfærdsforanstaltninger, tryghedsregler o.s.v. skaber ingen positiv motivation hos arbejderne, men manglende opfyldelse af disse faktorer kan skabe utilfredshed. Amerikanerne kalder dem derfor for vedligeholdelsesfaktorer.

Vedligeholdelsesfaktorerne er nødvendige for at tiltrække og fastholde arbejdskraft på samme måde, som det er nødvendigt for landmanden at tilberede og tilså sin jord for at kunne høste.

Men ligesom landmanden har opdaget, at han kan forbedre sit udbytte gennem omhyg- 
gelig pasning af sin avl, på samme måde er industrien i USA nu ved at opdage, at den kan forbedre sin effektivitet - og samtidig give sine arbejdere en fornuftigere mening med tilværelsen - ved at gøre brug af de fire motivationsfaktorer: Udvikling - handlemulighed - ansvar og anerkendelse.

Studieholdet har som nævnt set beviser på, at man i USA har nået forbløffende resultater ved anvendelse af disse 4 faktorer.

For virksomhedernes vedkommende har resultaterne været betydelige forøgelser af effektiviteten, og for arbejderne har det været en forøgelse af arbejdstilfredsheden, som naturligvis kan være vanskelig at måle, men som f.eks. viser sig gennem en betydelig reduktion af antallet af forsømmelser.

\section{[Kritik af LO's rode betonkning]}

Disse nyere ledelsessynspunkter har en særling interesse herhjemme i forbindelse med den aktuelle diskussion omkring demokrati på arbejdspladsen, og jeg skal derfor til afslutning forsøge at holde de amerikanske resultater op mod tankegangen i LO's røde betænkning.

Hvis vi et øjeblik gør den forudsætning, at de motivationsfaktorer, som har vist deres værdi i USA, også er gyldige her i landet, så står det jo klart, at de foreslåede virksomhedsnævn med medindflydelse og medbestemmelse simpelthen aldrig vil kunne opfylde deres erklærede formål, som jo er at medvirke til skabelse af øget arbejdstilfredshed for medarbejderne og en fortsat stigende effektivitet i virksomhederne.

For at opfylde disse formål, skal virksomhedsnævnene i følge LO's forslag - med forskellige grader af indflydelse varierende fra adgang til informationer og rådgivning til egentlig medbestemmelse - beskæftige sig med arbejdsforhold, velfærdsforhold, personalepolitiske forhold og forskellige forhold omkring produktion og økonomi - altså med de forhold som hører ind undet det, amerikanerne kalder for vedligeholdelsesfaktorer.

Også selve virksomhedsnævnene er jo en foranstaltning, som gennemføres for en flerhed af arbejdere og bliver derfor i sig selv en sådan vedligeholdelsesfaktor. Og vedligeholdelsesfaktorerne har jo netop vist sig ikke at kunne skabe effektivitet og arbejdstilfredshed - det der var virksomhedsnævnenes formål.
$\mathrm{Nu}$ ved vi intet om, hvorvidt motivationsfaktorer og vedligeholdelsesfaktorer er de samme i USA og i Danmark.

I USA har man gennemført undersøgelser både i de nordøstlige stater og i Texas og fundet overensstemmelse mellem resultaterne. Men amerikanerne understregede, at disse nyere ledelsessynspunkter, som har vist så gode resultater i USA måske ikke vil kunne anvendes i Europa.

Det er muligt, at de ikke kan bruges her i landet - vi må jo erkende, at der stadig er en betydelig forskel i levestandard og uddannelsesniveau - og måske også i mentalitet - mellem USA og Danmark. Men så længe vi ikke ved noget sikkert herom, så længe ved LO altså heller ikke, om de foreslåede virksomhedsnævn overhovedet er i stand til at opfylde deres formål.

\section{[Imødegå socialisering]}

Der er noget paradoksalt $i$, at arbejdsgiverne i USA giver deres medarbejdere handlemulighed og ansvar for at imødegå en fremtidig socialisering, medens danske arbejdere søger at fremme dette formål ved at stille krav om nøjagtig de samme ting.

Når man arbejder som industrikonsulent, forsøger man jo altid at basere sine forslag på de flest mulige kendsgerninger. Det var måske en idé, om arbejdsmarkedets organisationer tog initiativ til, at der blev gennemført en undersøgelse her i landet med henblik på at få bragt nogle kendsgerninger ind i diskussionen om, hvordan man kan skabe øget arbejdstilfredshed for medarbejderne og fortsat stigende effektivitet i virksomhederne.

Og lad mig så til slut sige, at jeg er fuldstændig klar over, at jeg løber en risiko for at blive betragtet som en naiv sjæl, når jeg sådan afslører min tro på disse nye, amerikanske ledelsessynspunkter. Men når man har talt med de mennesker, som anvender dem i praksis - og det er jo praktiske produktionsfolk med ansvar for afdelinger, som er betydeligt større end de fleste danske industrivirksomheder - så kan man ikke undgå at blive smittet af deres begejstring for de resultater, der faktisk er opnået.

Disse ledere mente selv, at de med frigørelse af det enorme potentiel, som medarbejderne har vist sig at være i besiddelse af, i virkeligheden står på tærsklen til en afgørende ny epoke i den industrielle udvikling. 